\title{
Suicídio de idosos sob a perspectiva de gênero
}

\author{
Suicide in the elderly from a gender perspective
}

Stela N azareth M eneghel ${ }^{1}$

Denise M achado Duran Gutierrez ${ }^{2}$

Raimunda M agalhães da Silva ${ }^{3}$

Sonia Grubits ${ }^{4}$

Lilian ZielkeH esler ${ }^{5}$

Roger Flores Ceccon ${ }^{5}$

${ }^{1}$ Escola de Enfermagem, UniversidadeFederal do Rio Grandedo Sul. RuaSão Manoel 963, Rio Branco. 90620-110 Porto Alegre RS. stelameneghel@gmail.com

${ }^{2}$ Faculdade dePsicologia, Departamento dePsicologia, UniversidadeFederal do Amazonas

${ }^{3}$ Centro de Ciências da

Saúde, M estrado em Saúde Coletiva, Universidade de

Fortaleza.

${ }^{4}$ Programa de M estrado Pós

Graduação em Psicologia,

UniversidadeCatólica D om Bosco.

${ }^{5}$ Grupo deEstudosem Saúde Coletiva, Escola de

Enfermagem, Universidade Federal do Rio Grandedo

Sul.
Abstract This study examines the relationship between suicide and aging from a gender perspective, examining the socially imposed boundaries of masculinity and femininity in the lives of elderly people who committed suicide. It is a qualitative study in which 50 psychosocial autopsies conducted with elderly relatives were selected from 10 cities in the N orth, South, N ortheast and M idwest of Brazil. In this article we have identified situations of gender vulnerabilities in the lives of 13 people who committed suicide: 10 men and 3 women selected for their exemplary character. Two main categories were listed: the first refers to femininity including the "gender destiny" experienced by elderly women who commit suicide when they can no longer care for themselves or work. The second concerns the hegemonic masculinity in crisis, in which old men die after changing from the role of providers due to retirement or illness. It should be stressed that gender norms, codes of honor, power inequalities and stereotypes affect both women and men in terms of susceptibility to suicidal behavior.

Key words Gender, Suicide, Femininity, Masculinity
Resumo Este estudo explora a relação entre suicídio e envel hecimento na perspectiva de gênero, analisando as demarcações socialmente impostas demasculinidadeefeminilidadena vida deidosos que cometeram suicídio. Trata-se de estudo qualitativo no qual foram consideradas 50 autópsias psicossociais realizadas com familiares de idosos, pertencentes a 10 municípios brasileiros, nas regiões N orte, Sul, N ordeste e Centro- $O$ este. N este artigo foram identificadas situações referentes a vulnerabilidades de gênero na vida de 13 pessoas que se suicidaram: 10 homens e três mulheres, selecionados pelo seu caráter de exemplaridade. Duas categorias princi pais foram elencadas: a primeira refere-seàsfeminilidades, incluindo o "destino de gênero" vivido por mulheres idosas que se suicidam quando não podem mais cuidar e trabalhar. A segunda refere-se a crises nas masculinidades hegemônicas, em quehomensidosos morrem após mudanças nos papeis de provedores, ocasionadas pela aposentadoria ou doença. Ressaltase que as normas de gênero, os códigos de honra, as desigualdades de poder e estereótipos afetam tanto as mulheres quanto os homens em relação à vulnerabilidade para comportamentos suicidas. Palavras-chave Gênero, Suicídio, Feminilidade, Masculinidade 


\section{Introduction}

High rates of suicide, attempts and suicidal ideation make this issue a highly relevant public health problem. In most western countries suicide attempt rates are high among women, while completed suicide is more frequent among men. This situation has been described as the "suicide paradox"1. Considering completed suicide only, it is a male problem; however, when one includes attempts the rate increases significantly among women ${ }^{2}$. N evertheless, little attention has been paid to differences in suicidal behavior in terms of gender and gender perspectives are still seldom studied ${ }^{3}$.

The predominant epidemiological pattern of suicideis one of mortality rates three to four times higher among men ${ }^{4}$, which is usually explained by biologicist arguments that include greater le thality of means used by men ${ }^{5}$. In Asia suicide rates are similar among men and women ${ }^{2,6}$ and worldwide only China and India have greater female mortality than male ${ }^{7,8}$.

In countries where female suicide rates are low, this issue is perceived as a male behavior because it is believed that carrying it out requires a level of energy and courage that is only found in men; on the other hand attempts are considered female and women are regarded as unable to complete the suicidal act. In countries with high female suicide rates the explanation is the opposite: the act is regarded as a sign of weakness and passivity that is typical of women ${ }^{1}$.

Thedistinct differencein suiciderates between genders is influencing debate about the importance of gender conditions to this event ${ }^{1,9-13}$. We use J oan Scott's ${ }^{14}$ gender concept, which considers it a complex, socially constructed category in which thereare differences in power between genders. Distinctions are of a social and not biological nature; there is also a relational aspect according to which the male gender can only be understood as complementary to the female.

Studies show higher prevalence of suicide among married women ${ }^{15,16}$, while others report higher rates among single, recently separated, divorced women and widows $5^{6,10,17}$. Thereisa greater chance of suicide among single and young married women, especially when the marriage occurs at an early age and when there is no autonomy in their choice of husband and decisions about their sexual and reproductivelives ${ }^{18}$. Early sexual activity in conservative communities, the presence of abortions, unwanted pregnancies and body image issues, including use of breast implants and bulimia, may all pose additional risk ${ }^{3}$. Domestic violence and sexual abuse, in addition to conservative gender and mental suffering patterns ${ }^{2}$ are predictors of self-harm. Women's involvement in activities that involverisk of violence such as prostitution are exposed to high suicide rates ${ }^{19,20}$. In summary, gender inequalities are conditions associated with suicide among women.

Work, as an activity that promotes social integration and autonomy, may be a protection factor for both genders; higher suiciderates have been observed in unemployed individual $s^{21}$. Authors have been pointing out ${ }^{9,22,23}$ that economic crises lead to men's failure as family providers; this produces conflict, consumption of alcohol and other drugs, emotional suffering and as a last resort suicide. M en have greater suicidemortality rates in societies wherehegemonic maleroles are in crisis; in such societies men find it difficult to fulfill their normative work-related role ${ }^{24}$ and they see their identity at risk.

The rate with which women join the workforce represents an overburden on women and risk of suicide for both genders ${ }^{25}$. The division of work between genders within thecontext of contemporary society means that female risk increases when women start playing the same roles as men while being exploited by typical competitiveness of the capitalist system.

With respect to the elderly, power hierarchies between genders are still present and natural, grounded in a model that emphasizes male authority over females and children ${ }^{26}$. Elderly women have been socialized according to rules that deny their own needs in order to care for others, whether their husbands, children or family members. $M$ aleelderly individuals, on the other hand, are at risk when they step away from work, when there are relationship conflicts or in situations where their codes of honor and masculinity are threatened.

Gender-related behavior has been playing a secondary role when one analyzes what determines vital events; this makes it crucial to study gender-based behavior with respect to suicide.

With our research we propose to study the relationship between suicide and the ageing process under the perspective of gender, analyzing socially imposed masculinity and femininity limits in the lives of elderly individuals who have committed suicide. 


\section{Methodological Journey}

This is a qual itative study for which information has been gathered with family members through psychosocial autopsies of elderly individuals who committed suicide. This investigation is part of a study called "Is it possibleto prevent theend from coming early? Suicidein the Elderly in Brazil and Possibilities for Action in the Heal thcareSector" ${ }^{27}$.

The first stage of this work consisted of de fining Brazilian cities that had the highest suicide rates among the elderly. After that 10 municipalities were selected which had the following: high coefficients of mortality; providing easy access and logistics; relying on a network of services that could back up this research; and representing all five macro-regions in the country. Procedures to identify people who committed suicide in the last five years varied according to each location; some began by conducting a survey at the local Office of the Chief M edical Examiner, whileothers contacted Municipal Secretariats for Health. The goal was to conduct in-depth interviews with families and/or acquaintances of those elderly individuals.

In most places surveyed, the masculinity ratio of suicide was at approximately four to one, similar to that of the Brazilian population ${ }^{4}$. For this reason it was difficult to find a high rate of female suicides for psychosocial autopsies.

After elderly individual swereidentified informants were contacted and interviews werescheduled. In each municipality five interviews were conducted with family members or friends of people who committed suicide, compiling an intentional sample of 50 people across the country.

An interview guide was then drafted based on questions pertaining to the research, adapted from prior studies ${ }^{28}$ and gathering data on: personal and social information relating to the individual who had committed suicide; the victim's family genogram in order to rebuild bonds, conflicts, relationship network and pattern of morbidity or mortality associated with the suicide; and semistructured interviews to detail themental state that preceded suicide, to describe situations associated with suicidal behavior and possiblecauses; retracing suicide and factors involved; understanding itsimpact on families and identifying the presence of gender vulnerability in the lifehistory of people who committed suicide.

Such instruments are part of the psychosocial autopsy that constitutes the retrospective approach in the case of suicide. It allows clarifying death situations based on relevant facts in the lives of suicidal individuals and their sociocultural context. This helps unveil their relational universe and possible causes related to the act. This construction was inspired by Shneidman's psychological autopsy technique ${ }^{29}$, which develops several explanations about causes and possibilities of suicide prevention. For this author, the importance of autopsies does not lie in promoting a single type of analysis, but rather in presenting different perspectives of the problem.

After interviews were conducted, data were gathered and organized into a corpus so that preanalysis could be performed. The aim was to organize life histories, triggering factors, a description of the act and its repercussion on the family, culminating in an analytical summary of each case.

In this paper we studied the relationship be tween suicide and the gender category, or how relational characteristics between genders may havemadethoseindividuals morevulnerableand contributed to the fatal outcome. We chose 13 psychosocial autopsies among 50 interviews conducted in the first semester of 2011 across Brazil's five macro-regions. Below we report situations relating to those 13 autopsies involving 10 men and three women, indentified and selected due to their illustrative nature, that is, the extent to which they portray an event that is at the same time uniqueand universal. For each story we used a synthetic subheading that emerged from reading the biography of the individual who committed suicide.

This project was approved by the $\mathrm{Re}$ search Ethics Committee of the Oswaldo Cruz Foundation (CEP /FIOCRUZ) and all participants signed an Informed Voluntary Consent Form (TCLE). Ethical recommendations and precautions were observed and family members that were going through a grieving process were referred to reference service providers and are receiving care.

\section{Resultsand Discussion}

The Gender Perspective

in the Analysis of Suicide

We work under the assumption that gender rules are present in all societies and that in most situations they are unfavorable to women; however, they do not sparemen even when they are in a position of prominence and power ${ }^{30}$. In the case of several serious forms of violence, howev- 
er, men are the main victims and this is how suicides appear, when seen from their population perspective. Therefore, gender is considered a suicide vulnerability factor both for men and women. From this perspective, femininity and masculinity features grounded in the patriarchal model, a system of power where men control women ${ }^{31}$, have been generating a "structural trap" where both genders are penalized. Within the context of power hierarchies between genders, self-annihilation may be perceived as the last possible strategy for those who have less power to influence the behavior of others ${ }^{1}$.

Gender differences may translate into vulnerabilities caused by how individuals are socialized. Gender roles through which men and women are differently educated remain throughout their lives, including old age. This education propagates a script according to which women are expected to be passive, delicate, and cordial, to repress their aggressiveness and take care of others in the family or in related professions. M en are ascribed the role of economically successful providers, in addition to being strong, assertive, potent and virile ${ }^{32,33}$. The excerpt below shows the gender roles performed by an elderly couple who had separated years beforehe committed suicide, in a story that ended with the following goodbye psalm: Have mercy on me Lord, for I am weak:

They were separated for ten years, our mother used to see him thin, dirty, she was sorry for him, and she said 'boy, come home'. He ended up living here, but he was al ways there with the other woman. In the last days he didn't pay for anything at home, what little money he got was for his daughter [of his other marriage]. I think he despaired over that, he was broke, unemployed and was ashamed to ask our mother for money to pay one hundred reais in child support every month. ( $N$ ortheast Region, male, 62 years old)

In the relational game, the first wife not only welcomes the ex-husband back into her home: 'boy, come home', she also pays child support for the daughter he had from another relationship. On theother hand, heis in the contradictory position of playing the honorable man who is able to meet his daughter's economic needs, but he gets the money from his ex-wife, on whom he depends financially. This ethical dilemma produces sadness, shameand unrest, which are many times pathologized and interpreted as depression by healthcare professionals.

$\mathrm{H}$ onor cultures of $\mathrm{M}$ editerranean regions are present in Brazil, especially in therural area. They define honor as a moral behavior and require men and women to follow codes of conduct according to which the reputation of group members is evaluated. Such arrangements take place within the context of patriarchal cultures that emphasizetraditional gender roles. In those scenarios there are high suicide rates ${ }^{34,35}$ and in our research we have found suicides motivated by honor among elderly individuals in several regions across the country.

One of the reasons behind high suicide rates among men has been attributed to the crisis of masculinity and the fact that men are unable to adapt to a changing world. This type of crisis may affect them in relational situations that are traditionally attributed to women, such as adultery, depending on a partner, punishment or revenge and custody disputes ${ }^{11}$ or even in situations where cultural roles are reversed and women are in charge of supporting the household financially while men do the domestic work.

Declinein function and the process of falling ill in old age may causemen to become impotent or individuals from both genders to become unable to work. Elderly women often lose the will to live after their children get married and leave the household.

\section{Worthless Femininities}

The cases selected in this chapter refer to elderly women who have committed suicide after having lived and fulfilled gender roles dictated by culture, according to which their value is measured according to how much they produce, serve and care for others. We have also selected men who were forced to take positions culturally assigned to women and where they felt powerless.

Women represented a smaller fraction in the selected sample. However, even in a small number many seemed to have fulfilled the "gender destiny" ${ }^{36}$ and caused their own death after a life grounded in traditional standards, where they rigorously performed all activities assigned to them as their social obligation.

In the life history called N ow that my youngest is married, I can die happily! one notices a strict performance of gender roles. A woman who was "all about work", taking care of everything and everyone in the house. Thus she played her socially attributed role to its fullest, in a subjective position of surrender ${ }^{32,33}$ :

She put up with everything. She never complained; she was all about work. She did things fast. She was very attached to her children. In the last few years, she took care of the house, clothes 
and the children. She retired, but she never had any money. She would hand it over to us immediately for us to do the shopping. She was happy because her youngest had gotten married. Then she said: Now, I can die happily. (South region, female, 62 years old)

Gender behaviors ${ }^{14,36}$ remain even in old age. This attitudecan beobserved in the life of a woman who committed suicide after following this script to the limits of physical resistance. Considered as the most productive in field work, despite being ill and obese, she was only afraid of no longer being able to work, blending the gender destiny - to serve and to care - with that of class - working as much as she could stand. The excess weight that marked her body is the same excess weight she carried throughout her life:

She worked a lot; if we were doing a job she would break in and do it. When she started having respiratory problems and pain she'd pray to God not to take her hands away. She worked the hardest in the field. She was scared of being stuck in a wheelchair and not being able to walk. She would say: I'm too fat, how are you going to take care of me? (South region, female, 60 years old)

The following stories depict the suffering caused by submission to gender roles and refer to an elderly woman whose story is summarized in a "life of suffering" in which "either the husband or the children would cause her trouble"; the other story describes a woman whose single life purpose seems to have been caring for others:

She suffered a lot, she lost her mother and had a difficult time in her childhood, she was upset by her husband who was unfaithful and had extramarital relationships, by the loss of one of her children when she were still a baby, and by her eldest daughter who moved out of her home to live with a man when she was ten, she was sad because one of her sons had been arrested for drug trafficking and by the loss of her husband. (M iddle West Re gion, female, 75 years old)

She took care of her parents until they passed away. Sheliked helping her family. Relatives would take out loans under her name and reassured her they would make the payments, but they never did and she ended paying them up. She kept that a secret and invested everything in her nephew. ( $N$ ortheast Region, female, 72 years old)

A situation that occurred in Brazil's Southeast region is the story of an 82-year-old woman who killed herself after a life that combined economic, family and gender vulnerabilities and multiple forms of violence. Self-immolation is a type of suicide used by women in contexts of in- equality, when they feel unempowered and turn their own death into a protest ${ }^{19}$.

After describing the gender vulnerability of those elderly women, we highlight narratives of men who are confronted with the need to play feminine underappreciated roles in families and society. An elderly man plays the role of a woman is about a farmer who began staying home and performing what was seen asfemaleactivities after hewas diagnosed with a tumor. This change represented the loss of this status as head of the family; after that important decisions started being made by his children and this may have triggered the ultimate self-harm:

He had prostate problems, so he almost didn't work anymore; he no longer went to the field. So he would stay home and do the housework and things like that, you know? (South Region, male, 74 years old)

Wehear stories about suicidal individuals sho had been abandoned by their partners, underappreciated or mistreated by them or who felt as complete failures in their marital relationships; this goes against the statements that women commit suicide over emotional issues and men over economic issues ${ }^{37}$.

With respect to loss of status in the marital relationship, after becoming a widower an elderly man married his sister-in-law, twenty years his junior. At the end of their lives they no longer got along and family members demanded that the wifecomply with so-called "wifeduties": Shedidn't take care of him, she didn't cook, they slept in separate beds and she was never home, she was always playing cards at the neighbors. The son sees that he was no longer in charge of the situation:

I believe heno longer had pleasure, he couldn't drive anymore. The second wife, we often went thereand shewould make a face. Dad loved having people over, welcoming them, but his second wife didn't. I was about two years since helast had control of things. Hewas man who would always take thelead and hemust havethought: my lifeis worthless now, why am I going to bother other people? (South Region, male, 84 years old)

In this relationship, the gender vulnerability affects thehusband, who is unable to "bein charge of thehouse" and to command his own life. Nevertheless, blaming the wife places other factors which may have influenced or determined this man's death on a secondary position.

In the same direction of men's unempowerment in terms of gender hierarchy we find the story of an elderly man in the countryside of Amazonas. $\mathrm{H}$ is principles and moral values were 
conservative, contrary to his wife, who did not fit the conventional gender patterns. Her sisters-inlaw would report 'offending' conducts to her husband; this would place the wife's reputation under suspicion, because she was communicative and enjoyed 'dressing up', dangerous behavior for patriarchal moral codes ${ }^{34,36}$. This situation is one of symbolic violence, where women themselves take control and watch over possible "deviants". The elderly man felt unable to fulfill his role as a male and according to his daughter: My father died of love (N orth Region, male, 80 years old)

Sensing the gender vulnerability in lifestories of elderly men and women who committed suicide can help us identify factors which may be rebuilt, strengthening such people.

\section{Fractured Masculinities}

M asculinity is a concept pertaining to men's position in gender relations and developed from the notion of "culturally hegemonic masculinity". It is defined as an arrangement based on the patriarchal model, on a structure of women being subordinated to male power ${ }^{38}$. Although not all men will adopt the dominant model, masculinity that is considered hegemonic emphasizes virility, aggressiveness and strength ${ }^{39}$.

In the western world, the hegemonic male role is defined according to four main attributes: stoicism (a man cannot express feelings), autonomy (heneeds to solve his problems without seeking help), success in all types of endeavors and aggressiveness. Difficulty in expressing one's feelings stems from this model and men who act accordingly are more vulnerable to suicide. This occurs mainly becauseseeking help for one's problems (economic, body limitations, illness) is seen as feminine behavior that implies weakness and lack of virility9,40,41.

Virility learned by and imposed on boys during socialization represents a collective and individual expression of male domination. Consequently, it consists of defense against suffering and fear engendered at work ${ }^{42}$, which takes a key role as a part of masculinity and of masculine identity ${ }^{43}$.

Narratives summarized here refer to obliterations of masculinities which generaterisk of selfharm. When performing conventional gender roles, a man will find it difficult to accept defeats, loss of power and authority, and suicide may be perceived as a way to "regain control" 40 or the only way out when facing a situation of powerlessness and suffering.
Below we tell two stories that correspond to the classic hegemonic model. One of them refers to an "aggressive and macho" elderly man and the other is about what we call "the community's moral support". The aggressive and macho elderly man was a tradesman from the Northeast region, a womanizer who wanted to seem challenging and unattainable. Heused to walk around carrying a knife on his waist as a symbol of his masculinity. He is thus portrayed by his son:

H e was always a womanizer, your girls, one of them 18 years old, were with him all day. This guy who pimped women threatened to kill my father and beat him up at a bus stop. From then on he was totally different, he closed down his business, hewas scared and saw that guy everywhere ( $N$ orth Region, male 63 years old).

The same gender imperative that orders men to take all opportunities to win a woman's affection is the same that makes them vulnerable and intensifies its risk components. In this narrativea strong male set of ideas stands out, which did not allow this man the necessary flexibility to come to terms with the violencehehad been subjected to ${ }^{44}$.

The story we call The community's moral support tells of an elderly man who was in conflict with ethical dilemmas arising from an extramarital relationship and being an exemplary individual in his family and community. Hewas professionally successful, loved and admired by those who surrounded him; everyone came to him for advice. After his suicide the family found out he had an extramarital relationship and that the woman was putting pressure on him to acknowledge the paternity of a child:

After the suicide the woman came over. It was two weeks since he'd found out that this woman had a little girl and said he was the father, but we found out it wasn't from a DNA test. Every older man likes a young woman to show off, he was 73 and shewas 29. (N ortheast Region, male, 73 years old)

Although they seem outdated, considering the changes that occurred in the last few decades, honor-based motives are still important for us to understand relational dynamics in suicidecases among the elderly. Those are people who started their social lives in times strongly influenced by conservative ideas; most of them lived in a rural environment where the male social role was and still is strongly associated with defending one's honor as a moral and social value.

In classical studies about the culture of honor ${ }^{45-47}$, the conflicting pair honor/shame estab- 
lishes norms, rules of conduct and hierarchies; however in each society it has different strength and features, even if it remains as an important reference in thestructure of unequal gender relationships.

Thepresence of illnesses, especially terminal, incapacitating or stigmatizing ones, represents another set of factors associated with suicide ${ }^{28}$. With respect to illnesses, we emphasize the importance of those which affect male genitals; in addition to pain and discomfort, they cause impotence.

The narrative we call I'm no longer a man for any woman! focuses on feelings stemming from the disease that affects virility. The subject of this narrative was a man of low income; he was a bricklayer who worked tirelessly and had custody of his children after separating. Several children died violently or got involved in criminal offences and were forced to move out of the house. At the end of his life he had undiagnosed chronic pain, which was possibly due to a prostate condition. According to the report:

Tests, medication, doctors just took away his money. He was very sad because three of his children had been killed by the hands of someone close. H e used to say that because of his condition [ prostate] hewas no longer a man for any woman (N orth Region, male, 68 years old).

In all Brazilian regions we found elderly individuals playing the role of the "womanizing macho" and who committed suicideafter being abandoned or cheated on, losing their malestatus propagated in patriarchal culture. "Between the Volkswagen Beetle and the club" is the story of an elderly man in the Middle West region who started being punished by his wife after "a romantic rendezvous with a young woman". Shewould hit him with a "club" and took away his "old Volkswagen Beetle", which was the thing he loved the most.

$M$ ale sexuality, which undergoes changes in old age aggravated by a prostate condition, represents a burden in the sense that it undermines identity references and perception of quality of life ${ }^{48}$. Just as the previous narrative, the story Kneeling in life and death is marked by the powerlessness caused by a prostate condition. It tells the story of a low-incomefarmer who continued working even though hewas sick, using a urinary catheter and adult diapers:

$\mathrm{He}$ would go to the field with the catheter and work with the hoe. M oney wasn't even enough to buy medication. Weused to begiven a meal. (South Region, male, 81 years old)
After getting sick this farmer became aggressive, especially with his wife who he started beating violently. Shefound him on his knees, defeated in death and in the life of a landless farmer: I got there and he was behind the gallows, he had the catheter on, he was on his knees!

The last report we identified under the category "fractured masculinities" is about leaving work after retirement, unemployment, illness or old age and the feeling of uselessness that comes from this state. Work-related suffering is present in fear of failure, in the feeling of uselessness caused by retirement, in the requirement to work until death and in the actual instance of dying "on his knees".

The story Time for him became endless is about a farmer who worked in the field planting tobacco ever sincehe was child. His work was the center and the meaning of this elderly man's life and physical incapacities contributed to having him stop working at the age of 80; this generated in him a feeling of powerlessness and unease.

H efelt lifeless; his life had no meaning, no work, and no companionship. Time for him became endless. (South Region, male, 92 years old)

On theSaturday prior to hissuicide, hewanted to take part in planting tobacco, but his son told him no: you've already worked too much, you belong at home. Hehanged himself in a shed and he was there partly on his knees. Just as in his life as a farmer, defeated by financial and moral bankruptcy, death left him on his knees, subdued.

\section{The Contribution of a Gender Perspective} to Suicide Studies

In this article we prioritize issues that appear in psychosocial autopsies and that refer to gender issues; that is, how cultural differences between men and women can become factors that determine or increase the occurrence of suicide. Wehaveidentified the presence of gender-related conflicts or weaknesses in stories of elderly individuals in all Brazilian regions and not only in the thirteen stories we chose as representative of categories we worked on.

Weunderstand that gender norms affect both women and men with respect to risk of suicidal behavior. Although this was not the main goal, in this study such issues emerged in reports provided by family members and caretakers about the behavior of elderly individuals who committed suicide. Gender inequalities, stereotypes and vulnerabilities were present in the lives of women 
who committed suicide after rigorously playing feminine roles and in the lives of men in conflict with honor principles or with normative principles of dominant masculinity.

Depression caused by stepping away from work, retirement, illness or disability was another vulnerability factor according to people's training for work.

We attempted not to focus specifically on reports of mental illness; we understand that mental suffering may be caused by social behavior and does not need to be pathologized. Current literature overestimates the association between suicideand mental disorders ${ }^{49,50}$, wheresuicideis perceived as a symptom of an individual psychopathology and not as social behavior. We heard reports of depression in most stories about elderly individuals; however this condition isfrequent among the elderly population and diagnosis is often vulgarized and imprecise.

After finishing this study we believe that gender norms and codes of honor represent a scenario that increases risk of suicide. In that sense, we believe that using the gender category contributes to expanding the understanding of this phenomenon, and understanding aspects to be taken into account in primary and secondary healthcare approaches.

\section{Collaborations}

SN M eneghel, DM D Gutierrez, RM Silva, SGrubits, LZ Hesler and RF Ceccon participated equally in all stages of preparation of the article. 


\section{References}

1. Canetto S. Women and Suicidal Behavior: a cultural analysis. American J of Orthopsychiatry 2008; 78(2): 259266.

2. Drevies K, Watts $C$, Yoshihama M, Kiss L, Schraiber LB. Violence against women is strongly associated with suicide attempts: evidence from the WHO multicountry study on women's health and domestic violenceagainst women. SocSci M ed 2011; 73:79-86.

3. Beautrais AL. Women and suicidal behavior. Crisis 2006; 27(4):153-156.

4. Mello-Santos C, Bertolete JM, Wang YP. Epidemiology of suicide in Brazil (1980-2000). Rev Bras Psiquiatr 2005; 27(2):131-134.

5. Callanan VJ, Davis MS. Gender differences in suicide methods. Soc Psychiatry Psychiatr Epidemiol 2011; [Epub ahead of print]

6. Organização Mundial deSaúde. Relatório M undial sobre Violência eSaúde: Sumário. Geneve, 2002.

7. Yip PSF, Liu KY, Law CK. Years of life lost from suicide in China, 1990-2000. Crisis 2008; 29(3):131136.

8. Zhang J, Wieczorek W, Conwell Y, Tu XM, Wu BYW, Xiao S, Jia C. Characteristics of young rural Chinese suicides: a psychological autopsy study. Psycho M ed 2010; 40(4):581-589.

9. Cleary A. Suicidal action, emotional expression and the performance of masculinities. Soc. Sci. M ed. 2011; ePub(ePub):ePub.

10. Hawton K. Sex and suicide. Gender differences in suicidal behavior. British Journal of Psychiatry 2000; 177:484-485.

11. Shiner M, Scourfield J, Fincham B, Langer S. When things fall apart: gender and suicide across the lifecourse. Soc Sciences M ed 2009; 69(5):738-746.

12. Meneghel SN, Victora CG, Faria NM, Pinheiro L. Características epidemiológicas do suicídio no Rio Grande do Sul. Rev Saúde Pública 2004; 38:804-10.

13. Ghaill MM, Haywood C. Understanding boys: Thinking through boys, masculinity and suicide. Soc Sci M ed 2010; ePub(ePub):ePub

14. Scott JW. Gênero: uma categoria útil de análise histórica. Educação \& Realidade 1995; 2(2).

15. H aqqi S. Suicide and Domestic Violence: Could There BeaCorrelation? M edscapeJ M ed 2008; 10(12): 287.

16. Stefanello S, Cais CFS, M auro M LF, Freitas GVS, Botega NJ. Gender differences in suicideattempts: preliminary results of themultisiteintervention study on suicidal behavior (SU PRE-M ISS) from Campinas, Brazil. Rev BrasPsiquiatr 2008; 30(2):139-43.

17. Fairweather-Schmidt K, Anstey KJ, Saklim A, Rodgers $B$. Baseline factors predictive of serious suicidal at follow-up: findings focusing on age and gender from a community-based study. BM C Psychiatry 2010; 10:41.

18. Blumenthal S. Suicide and gender. [D ocument in Internet]. [cited 2012 jun 12] Disponível em: http://susanblumenthal.org/wp-content/uploads/2010/04/SusanBlumenthal-Suicide_and_Gender.pdf

19. Shahmanesh M, Wayal S, Cowan F, Mabey D, Copas $A$, Patel V. Suicidal behavior among female sex workers in Goa, India: the silent epidemic. Amer J Public Health 2009; 99(7):1239-1246.
20. Hong $Y$, Li X, Fang X, Zhao R. Correlates of Suicidal Ideation and Attempt Among Female Sex Workers in China. Health Care Women Int 2007; 28(5):490-505.

21. KposowaAJ. Unemployment and suicidea cohort analysis of social factors predicting suicide in US N ational M ortality Study. Psychological M edicine 2001; 31:127138.

22. M arín-León L, Barros M BA. M ortes por suicídio: diferenças de gênero e nível socioeconômico. Rev. Saúde Pública 2003; 37(3):357-363.

23. Morrell S, Taylor R, Quine S, Kerr C. Suicide and unemployment in Australia 1907-1990. Soc Sci M ed, 1993; 36:749-56.

24. Siqueira MJT. A constituição da identidade masculina: alguns pontos para discussão. Psicologia U SP 1997; 8(1):113-130.

25. Fernquist RM. Gender equality and the sex differential in suicide rates using gender-age standardized data. Arquives of Suicide Research 1999; 5:255260.

26. Figueiredo WS. Assistência á saúde dos homens: um desafio para os serviços de atenção primária. Cien Saude Colet 2005; 10(1):105-109.

27. M inayo MCS, Cavalcante FG. É possível prevenir a anteci pação do fim? Suicídio del dosos no Brasil epossibilidades deA tuação do Setor Saúde. [Projeto depesquisa]. Rio deJaneiro: CLAVES, Fiocruz; 2010.

28. M inayo M C. A autoviolência. Objeto da sociologia eproblema de saúde pública. Cad. Saúde Pública 1998; 14(2):421-428.

29. Shneidman ES. Autopsy of a Suicidal Mind. [S.I.]: Oxford University Press; 2004

30. SinghJA, Bandewar S, Singer PA. Sex, gender, and health biotechnology: points to consider, BM C International $H$ ealth and H uman Rights 2009; 9:15.

31. Rodriguez JCR. Y eso de masculinidad? Apuntes para una discusión. In: Careaga G, Sierra SC, organizadores. Debates sobre masculinidades - poder, desarollo, políticas publicas y ciudadania. M éxico: UNAM ; 2006. p. 31-56.

32. Oliveira PP. A construção social da masculinidade. Belo H orizonte: Editora da U FM G; 2004.

33. Grossi M P. M asculinidades uma revisão teórica. Antropologia em primeira mão 1995; (1):1-37.

34. Vandello JA, Cohen D. Malehonor and femalefidelity: implicit cultural scripts that perpetuate domestic violence. Journal of Personality and Social Psichology 2003; 84(5): 997-1010.

35. Osterman LL, Brown RP. Culture of Honor and violence against the self. Pers. Soc Psychol. Bul. 2011; 37(12):1611-1623;

36. Bourdieu P. A dominação masculina. 2ª ed. Rio de Janeiro: Bertrand do Brasil; 2002.

37. Sadet N, Javdani S, Finy MS, Verona E. Gender difference in emotional risk for self - and other directed violence among externalizing adults. Journal of Consulting and Clinical Psychology 2011; 79(1): 106-117.

38. Connell RW. Masculinities. Berkeley, Los Angeles: University of California Press; 2005. 
39. Schofield T, Connell RW, Walker L, Wood JF, Butland DL. Understanding M en's Health and IIIness: A Gender Relations Approach to Policy, Research, and Practice. J Am Col Health 2000; 48(6):247-256.

40. Houle J, M ishara B, Chagnon F. An empirical test of a mediation model of the impact of the traditional male gender roleon suicidal behavior in men. Journal of AffectiveD isorders 2008; 107:37-43.

41. Braz M. A construção da subjetividade masculina e seu impacto sobre a saúde do homem: Reflexão bioética sobrejustiça distributiva. Cien SaudeC olet 2005; 10(1):97-104.

42. Molinier $P$, Welzer-Lang $D$. Feminilidade, masculinidade, virilidade. In: Hirata H, LaborieF, LeD oari H, Senatier D, organizadores. Dicionário deFeminismo. São Paulo: EditoraUNESP; 2009. p. 101-105.

43. Nolasco S. 0 mito da masculinidade. $2^{2}$ ed. Rio deJaneiro: Rocco; 1995.

44. Gomes R, Nascimento EF, Araújo FC. Porque os homens buscam menos os serviços de saúde do que as mulheres? As explicações de homens com baixa escolaridade homens com ensino superior. Cad. SaúdePública 2007; 23 (3):565-574.

45. Rohden F. Para que serve 0 conceito de honra, ainda hoje? Campos 2006; 7(2):101-120.

46. Peristiany JG, organizador. H onra e Vergonha: valores das sociedades mediterrâneas. Lisboa: Fundação Calouste Gulbenkian. Original de 1965, 1971.

47. Peristiany JG, Pitt-Rivers J, editor. H onor and Grace in Anthropology. Cambridge: CambridgeU niversity Press, 1992.

48. Gomes R, Nascimento EF. A produção de conhecimento da saúde pública sobre a relação homem saúde: Uma revisão bibliográfica. Cad. SaúdePública 2006; 22(5):901-911.

49. Parkar SR, Dawani V. Gender, suicide and the sociocultural context of deliberate self-harm in a Urban General Hospital in Mumbai, India. Cult Med Psychiatry 2008; 32:492-515.

50. Monnin J, Thienard E, Vandel $P$, Nicolier $M$, Tio G, Courtet P, Bellivier F, Sechter D, Haffen E. Sociodemographic and psychopathological risk factors in repeated suicide attepts: gender differences in a prospective study. Journal of Affective Disorders 2011 [article in press]. 